Egyptian Journal of Aquatic Biology \& Fisheries

Zoology Department, Faculty of Science,

Ain Shams University, Cairo, Egypt.

ISSN $1110-6131$

Vol. 25(2): $385-402$ (2021)

www.ejabf.journals.ekb.eg

\title{
Survey on the most common bacterial pathogens of the Nile tilapia fries in Kafr El sheikh governorate, Egypt
}

\author{
Ahmed Arafa, Nehal A. Younis, Mohamed Moustafa, Mohamed A. Abdelaziz* \\ Department of Aquatic Animal Medicine and Management, Faculty of Veterinary Medicine, \\ Cairo University, Giza, Egypt \\ *Corresponding Author : mabdelaziz1973@yahoo.com
}

\begin{abstract}
ARTICLE INFO
Article History:

Received: Dec. 26, 2021

Accepted: March 22, 2021

Online: April 15, 2021

Keywords:

tilapia fries, Aeromonads,

S. epidermidis,

Shigella sonnei,

Providencia rettgeri,

Acinetobacter lwoffii

\section{ABSTRACT}

Recently, aquaculture in Egypt has faced multiple records of mass mortality resulting in high economic losses. The mass mortality among tilapia fries is mostly attributed to bacterial pathogens either with or without other pathogens. This study is designed to investigate the etiological factors implicated in mortality of the Nile tilapia fries. Bacteriological examination of the Nile tilapia fries including isolation and identification using a range of techniques (API NE20, Vitec, PCR and 16SrRNA Sequencing) revealed an array of typical pathogens known to cause lethal infections in tilapia. The most frequently isolated strains were Aeromonads 33.3\% (A. veronii, A. sobria, A. hydrophila), Staphylococcus epidermidis, $11.1 \%$ Pseudomonas aeruginosa, $11.1 \%$ and Shigella sonnei $11.1 \%$. Furthermore, three emerging freshwater aquaculture pathogens which have zoonotic significance, namely Providencia rettgeri (11.1\%), Shewanella putrefaciens (11.1\%) and Acinetobacter lwoffii $(11.1 \%)$ were isolated from fish fries. Despite known pathogenicity, inoculation of fish fingerlings with the different bacterial isolates resulted in only mild mortality rates under non-stress conditions, emphasizing the role of additional environmental stressors in triggering mass mortality of juvenile fish. Conclusively, these pathogens have a significant negative impact on tilapia fries, particularly in combination with environmental stress.
\end{abstract}

\section{INTRODUCTION}

Fish is considered as food resource that could help to meet food security needs across the globe, particularly in developing and populous countries. Fish currently represents around 16 percent of all animal protein consumed globally (FAO, 2018). Moreover, fish constitutes about 30 percent of all animal protein intake in the developing countries (Wang et al., 2015). Aquaculture, in particular, has played a major role over the past decades by increasing the production of fish efficiently and at an affordable cost. It currently accounts for more than half of worldwide fish production (Subasinghe et al., 2009). Recently, Egypt ranks the tenth in fish farming production and the first among African countries, the industry employs more than 
580,000 workers and contributes to around 77 percent of the total fish production in Egypt (GAFRD, 2014; FAO, 2016). The majority of fish farms are located close to the Nile in the northern part of Egypt and the Delta region (FAO, 2018). Kafr ElSheikh, Damietta, Port Said, Fayoum, Behira, and Sharkia are the leading governorates in aquaculture production (GAFRD, 2014). Tilapia is the most predominant species in fish farms, representing about 55 percent of the total production of aquaculture, (Sadek, 2013). However, aquaculture in Egypt suffers from elevated mortality due to parasites, bacteria, fungi, and viruses, resulting in high economic losses. These pathogens have a significant negative impact on feed conversion rates and postinfection total weight of fish that could not recover (Shaalan et al., 2018). Besides, environmental issues as abrupt thermal changes, extreme reduction in dissolved oxygen and high ammonia levels, are major reasons for mass mortalities among fish populations (Harris et al., 1998). In fish farms, high mortality rates are attributed to bacterial rather than other infections. In Egyptian fish farms, infections with Aeromonas hydrophila, Flavobacterium columnaris, Pseudomonas fluorescens, Yersinia ruckeri, Edwarsiella tarda, Edwardsiella ictaluri, Vibrio spp. Mycoplasma and Streptococcus spp. are prevalent (Moustafa et al., 2010; Zhang et al., 2014; Abdelsalam et al., 2017; El-jakee et al., 2020). Pseudomonas is reported to be an important cause for Egyptian aquaculture outbreaks in the last decade (Khalil $\boldsymbol{e t}$ al., 2010). Aeromonas species have also been isolated from some fish farms in Egypt (Khairul Afizi et al., 2013; Noor El-Deen et al., 2014). Lactococcosis, Enterococcosis and Streptococcosis are found in tilapia farms in Egypt. Additionally, ammonia, high water temperature, organic matter, fish density, low oxygen level and $\mathrm{pH}$ are regarded as predisposing factors. Thus, a proper management is the first preventive measure needed to avoid outbreaks in fish farms (Abu-elala et al., 2020a).

Hence,this study was designed to investigate the most common bacterial causes of mortality rates among tilapia fries.

\section{MATERIALS AND METHODS}

\section{1- Sample collection:}

Six thousand tilapia fries (Oreochromis niloticus) were collected from Kafr El Sheikh hatcheries with average body weight of $0.65 \mathrm{~g}$ and average length $0.5 \mathrm{~cm}$.Fish samples were transported in clean plastic bags to the laboratory of Aquatic animal's medicine and management, faculty of Veterinary Medicine, Cairo University for bacteriological examination. Water samples were collected in clean sterile glass bottle for water analysis.

\section{2- Water analysis:}

Water samples were used to analyze $\mathrm{BOD}, \mathrm{COD}, \mathrm{NH}_{3}, \mathrm{NH}_{4}, \mathrm{NO}_{2}, \mathrm{Fe}, \mathrm{Cu}, \mathrm{Cd}$, and $\mathrm{Pb}$ in the central laboratory for water analysis, faculty of Agriculture, Cairo University 
according to the international standard methods for examination of water and wastewater (APHA, 2005).

\section{3- Bacterial isolation and identification:}

Under complete aseptic conditions, swab from grinded pooling samples of fries was streaked on Nutrient agar, Todd Hewitt agar, tryptone soya agar, blood agar and pseudomonas agar media after external sterilization by $70 \%$ ethyl alcohol and incubated at $28^{\circ} \mathrm{C}$ for $24-48 \mathrm{hrs}$. according to Whitman and MacNair (2004).

A single colony from isolate was picked up, re-streaked again on the aforementioned media, and re-incubated at the same conditions for purification of bacterial isolates. When pure colonies were identified by gram stain, a loopful of each pure culture was streaked onto trypticase soya agar media to be used for further identification. Identification of all isolates were done by cultural, morphological and biochemical characters (Austin \& Austin, 2007; Panangala et al., 2007; Quinn et al., 2011).

\section{3-1- Biochemical identification:}

Biochemical identification was performed using API20NE following manufacturer's instructions (bioMerieux), and Vitek Analysis was done according to the manufacture's instruction (Biomeriux, 2006) in the department of fish diseases and management, animal health research institute, Dokki, Egypt.

\section{3-2-Molecular identification (PCR and sequencing):}

Total bacterial DNA was extracted from pure colonies of four isolates using GeneJet genomic DNA purification Kit (ThermoFisher, USA) according to the manufacturer's instructions. PCR for 16SrRNA was done using universal primers (Forward: 5'- AGA GTT TGA TCC TGG CTC AG-3') (Reverse: 5'-GGT TAC CTT GTT ACG ACT T-3') reported elsewhere (Weisburg et al., 1991)by Maxima Hot Start PCR Master Mix (ThermoFisher, USA) as per manufacturer's instructions. Reaction conditions were as follows: Initial denaturation step at $95{ }^{\circ} \mathrm{C}$ for $10 \mathrm{~min}$; thirty-five cycles of denaturation at $95{ }^{\circ} \mathrm{C}$ for $30 \mathrm{~s}$, annealing at $65{ }^{\circ} \mathrm{C}$ for $1 \mathrm{~min}$, and extension at $72{ }^{\circ} \mathrm{C}$ for $1 \mathrm{~min} 30 \mathrm{~s}$; A final extension was done for $10 \mathrm{~min}$ at $72{ }^{\circ} \mathrm{C}$. The reaction volume was $50 \mu \mathrm{l}$. The amplified products were analyzed by electrophoresis on $1 \%$ agarose gel stained with ethidium bromide.

16SrRNA was sequenced in both directions using ABI 3730xl DNA sequencer (Applied BiosystemsTM, USA) at Sigma Scientific Services Laboratory (Cairo, Egypt). Sequences were compared to reference sequences using BLAST® of NCBI (Altschul et al., 1990).

\section{4- Pathogenicity Test:}

A total number of 50 healthy Oreochromis niloticus fingerlings, with average body weight of $20 \mathrm{gm}$, were held in aerated freshwater aquaria supplied with dechlorinated 
tap water at $25^{\circ} \mathrm{C} \pm 2$ for ten days before challenge for acclimatization. Tilapia under the experiment were divided into four groups (Ten fishes for each group). Each group was injected intraperitoneal with $0.2 \mathrm{ml}$ of bacterial isolates (Table 1). The first, second, third and fourth group (control) was injected intaperitoneal with $6 \times 10^{8} \mathrm{CFU} / \mathrm{ml}$ of Aeromonas Veronii, $3 \times 10^{8} \mathrm{CFU} / \mathrm{ml}$ of Staphylococcus Epidermidis, $6 \times 10^{8} \mathrm{CFU} / \mathrm{ml}$ of Providencia Rettgeri and saline-respectively. After the inoculation, the fish were observed for three weeks; during which the clinical signs, morbidity, and mortality percent were recorded (Huang et al., 1999; Hassan et al., 2017; Ramesh \& Souissi, 2018).

Table 1: Doses of inoculated bacterial isolates.

\begin{tabular}{|l|l|}
\hline First group & $6 \times 108 \mathrm{CFU} / \mathrm{ml}$ of Aeromonas Veronii \\
\hline Second group & $3 \times 108 \mathrm{CFU} / \mathrm{ml}$ of Staphylococcus Epidermidis \\
\hline Third group & $6 \times 108 \mathrm{CFU} / \mathrm{ml}$ of Providencia Rettgeri \\
\hline Fourth group & Control group (saline only) \\
\hline
\end{tabular}

\section{RESULTS}

\section{1- Water Analysis:}

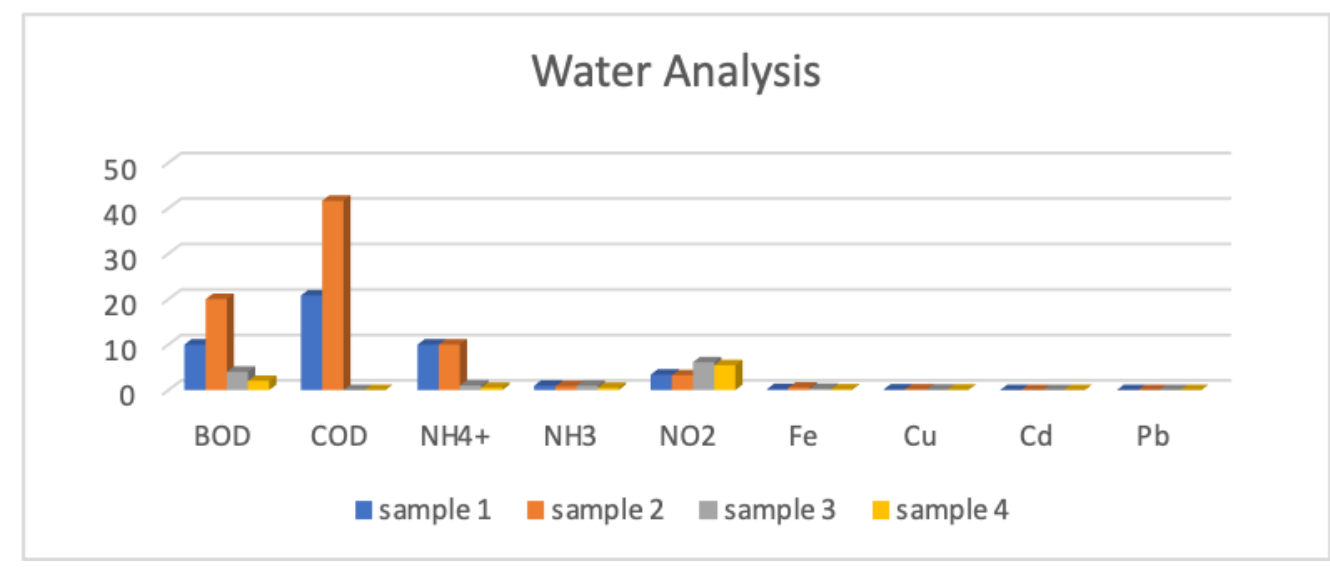

Fig.1: Results of examination of water samples from hatcheries.

BOD (Biological Oxygen Demand) ranged from 2 - $20 \mathrm{mg} / \mathrm{l}$. The highest value (20 $\mathrm{mg} / \mathrm{l}$ ) is observed at the second sample (spring), while the lowest value of $2 \mathrm{mg} / \mathrm{l}$ is observed at the fourth sample (summer). COD (Chemical Oxygen Demand) range from ND (Not Detected) to $41.6 \mathrm{mg} / \mathrm{l}$. The highest value $(41.6 \mathrm{mg} / \mathrm{l})$ is observed at the second sample (spring), while the lowest value of ND is observed at the third and fourth samples (summer). $\mathrm{NH}_{4}+$ ranged from $0.5-10 \mathrm{mg} / \mathrm{l}$. The highest value $(10 \mathrm{mg} / \mathrm{l})$ is observed at the first and second samples(spring), while the lowest value of $0.5 \mathrm{mg} / \mathrm{l}$ is observed at 
the fourth sample(summer). $\mathrm{NH}_{3}$ ranged from $0.47-0.95 \mathrm{mg} / \mathrm{l}$. The highest valueof 0.95 $\mathrm{mg} / \mathrm{l}$ is observed at the first samples(spring), while the lowest value of $0.47 \mathrm{mg} / 1$ is observed at the fourth sample(summer). Fe (Iron) ranged from $0.13-0.53 \mathrm{mg} / \mathrm{l}$. The highest value of $0.53 \mathrm{mg} / \mathrm{l}$ is observed at the second sample (spring), while the lowest value of $0.13 \mathrm{mg} / \mathrm{l}$ is observed at the fourth sample (summer). $\mathrm{Cu}$ (Copper) ranged from 0.05 to $0.13 \mathrm{mg} / \mathrm{l}$. The highest value of $0.13 \mathrm{mg} / \mathrm{l}$ is observed at the first sample (spring), while the lowest value of $0.05 \mathrm{mg} / 1$ is observed at the third and fourth samples (summer). $\mathrm{Cd}$ (Cadmium) and $\mathrm{Pb}$ (Lead) are ND (Not Detected) in all water samples.

\section{2- Isolation and Identification of bacterial isolates:}

\section{1- Cell morphology:}

The isolated species of bacteria are categorized according to Gram's stain into Gram-negative rods and Gram-positive cocci.

\section{2- Biochemical identification:}

\subsection{1- API20-NE Analysis:}

According to the API 20-NE identification, there was a strain from genus

Shewanella (Shewanella puterfaciens) (Fig.2).
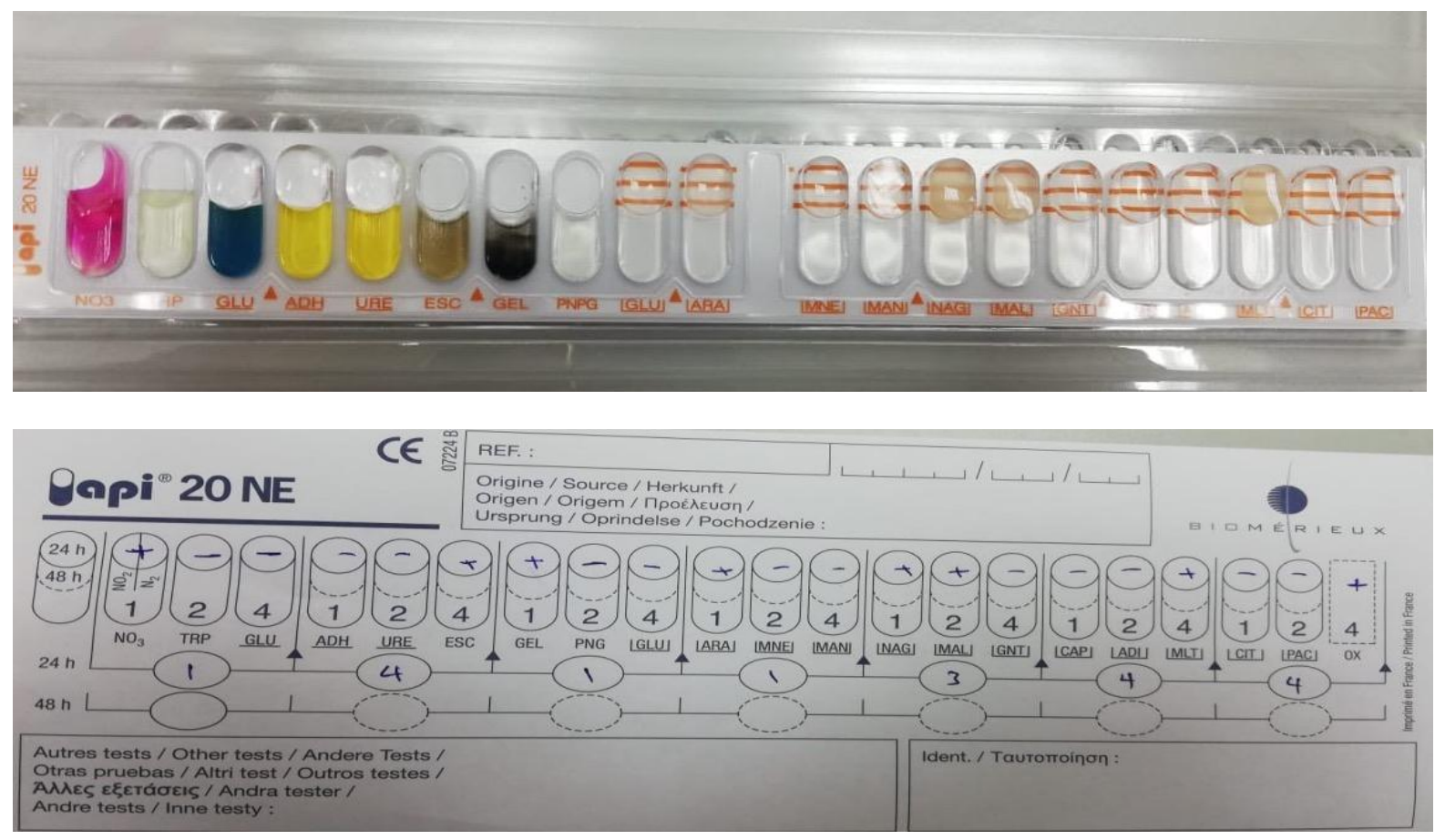

Fig. 2: API20- NE Strip used for identification of Shewanella puterfaciens. 


\subsection{2- Vitek analysis:}

Identification by Vitek2 compact system revealed the following (Tables $\mathbf{2 , 3}, \mathbf{4}, \mathbf{5}$ and 6):

1- Aeromonas sobria (86\% probability), Bio number (5675613150544271)

\begin{tabular}{|c|c|c|c|c|c|c|c|c|c|c|c|c|c|c|c|c|c|c|c|}
\hline \multicolumn{11}{|c|}{ Table 2: Biochemical details of Aeromonas sobria } \\
\hline 1 & - & & 2 & APPA & + & 3 & ADO & - & 4 & PyrA & + & 5 & IARL & - & 6 & - & \\
\hline 7 & dCEL & + & 8 & - & & 9 & BGAL & + & 10 & H2S & + & 11 & BNAG & + & 12 & AGLTP & + \\
\hline 13 & dGLU & + & 14 & GGT & - & 15 & OFF & + & 16 & - & & 17 & BGLU & - & 18 & dMAL & + \\
\hline 19 & dMAN & + & 20 & dMNE & + & 21 & BXYL & - & 22 & BAlap & - & 23 & proA & + & 24 & - & \\
\hline 25 & - & & 26 & LIP & + & 27 & PLE & - & 28 & - & & 29 & TyrA & + & 30 & - & \\
\hline 31 & URE & - & 32 & dSOR & - & 33 & SAC & + & 34 & dTAG & - & 35 & dTER & + & 36 & CIT & - \\
\hline 37 & MNT & - & 38 & - & & 39 & 5 KG & - & 40 & ILATK & + & 41 & AGLU & - & 42 & SUCT & + \\
\hline 43 & NAGA & - & 44 & AGAL & - & 45 & PHOS & + & 46 & GlyA & - & 47 & ODC & - & 48 & LDC & + \\
\hline 49 & - & & 50 & - & & 51 & - & & 52 & - & & 53 & IHISa & - & 54 & - & \\
\hline 55 & - & & 56 & CMT & + & 57 & BGUR & - & 58 & O129R & + & 59 & GGAA & + & 60 & - & \\
\hline 61 & IMLTa & + & 62 & ELLM & + & 63 & - & & 64 & ILATa & - & & & & & & \\
\hline
\end{tabular}

2- Aeromonas hydrophila (97\% probability), Bio number (050002003231231)

Table 3: Biochemical details of Aeromonas hydrophila

\begin{tabular}{|c|c|c|c|c|c|c|c|c|c|c|c|c|c|c|c|c|c|}
\hline 1 & - & & 2 & APPA & + & 3 & ADO & - & 4 & PyrA & + & 5 & IARL & - & 6 & - & \\
\hline 7 & dCEL & + & 8 & - & & 9 & BGAL & + & 10 & H2S & + & 11 & BNAG & + & 12 & AGLTP & + \\
\hline 13 & dGLU & + & 14 & GGT & - & 15 & OFF & + & 16 & - & & 17 & BGLU & - & 18 & dMAL & + \\
\hline 19 & dMAN & + & 20 & dMNE & + & 21 & BXYL & - & 22 & BAlap & - & 23 & proA & + & 24 & - & \\
\hline 25 & - & & 26 & LIP & + & 27 & PLE & - & 28 & - & & 29 & TyrA & + & 30 & - & \\
\hline 31 & URE & - & 32 & dSOR & - & 33 & SAC & + & 34 & dTAG & - & 35 & dTER & + & 36 & CIT & - \\
\hline 37 & MNT & - & 38 & - & & 39 & 5 KG & - & 40 & ILATK & + & 41 & AGLU & - & 42 & SUCT & + \\
\hline 43 & NAGA & - & 44 & AGAL & - & 45 & PHOS & + & 46 & GlyA & - & 47 & ODC & - & 48 & LDC & + \\
\hline 49 & - & & 50 & - & & 51 & - & & 52 & - & & 53 & IHISa & - & 54 & - & \\
\hline 55 & - & & 56 & CMT & + & 57 & BGUR & - & 58 & O129R & + & 59 & GGAA & + & 60 & - & \\
\hline 61 & IMLTa & + & 62 & ELLM & + & 63 & - & & 64 & ILATa & - & & & & & & \\
\hline
\end{tabular}


3- Providencia rettgeri (98\% probability), Bio number (0694212003231231)

\begin{tabular}{|c|c|c|c|c|c|c|c|c|c|c|c|c|c|c|c|c|c|c|}
\hline \multicolumn{11}{|c|}{ Table 4: Biochemical details of Providencia rettgeri } \\
\hline 1 & - & & 2 & APPA & - & 3 & ADO & + & 4 & PyrA & - & 5 & IARL & + & 6 & - & \\
\hline 7 & dCEL & - & 8 & - & & 9 & BGAL & - & 10 & H2S & - & 11 & BNAG & - & 12 & AGLTP & - \\
\hline 13 & dGLU & + & 14 & GGT & - & 15 & OFF & + & 16 & - & & 17 & BGLU & + & 18 & dMAL & - \\
\hline 19 & dMAN & + & 20 & dMNE & + & 21 & BXYL & - & 22 & BAlap & - & 23 & proA & - & 24 & - & \\
\hline 25 & - & & 26 & LIP & - & 27 & PLE & - & 28 & - & & 29 & TyrA & + & 30 & - & \\
\hline 31 & URE & + & 32 & dSOR & - & 33 & SAC & - & 34 & dTAG & - & 35 & dTER & - & 36 & CIT & + \\
\hline 37 & MNT & - & 38 & - & & 39 & 5 KG & - & 40 & ILATK & - & 41 & AGLU & - & 42 & SUCT & + \\
\hline 43 & NAGA & - & 44 & AGAL & - & 45 & PHOS & + & 46 & GlyA & - & 47 & ODC & - & 48 & LDC & - \\
\hline 49 & - & & 50 & - & & 51 & - & & 52 & - & & 53 & IHISa & - & 54 & - & \\
\hline 55 & - & & 56 & CMT & + & 57 & BGUR & - & 58 & O129R & - & 59 & GGAA & - & 60 & - & \\
\hline 61 & IMLTa & - & 62 & ELLM & + & 63 & - & & 64 & ILATa & - & & & & & & \\
\hline
\end{tabular}

4- Shigella sonnei (98\% probability), Bio number (0694212003231231)

\begin{tabular}{|c|c|c|c|c|c|c|c|c|c|c|c|c|c|c|c|c|c|c|}
\hline \multicolumn{11}{|c|}{ Table 5: Biochemical details of Shigella sonnei } \\
\hline 1 & - & & 2 & APPA & - & 3 & ADO & - & 4 & PyrA & - & 5 & IARL & - & 6 & - & \\
\hline 7 & dCEL & - & 8 & - & & 9 & BGAL & + & 10 & H2S & - & 11 & BNAG & - & 12 & AGLTP & - \\
\hline 13 & dGLU & + & 14 & GGT & - & 15 & OFF & + & 16 & - & & 17 & BGLU & - & 18 & dMAL & + \\
\hline 19 & dMAN & + & 20 & dMNE & + & 21 & BXYL & - & 22 & BAlap & - & 23 & proA & + & 24 & - & \\
\hline 25 & - & & 26 & LIP & - & 27 & PLE & - & 28 & - & & 29 & TyrA & + & 30 & - & \\
\hline 31 & URE & - & 32 & dSOR & + & 33 & SAC & - & 34 & dTAG & - & 35 & dTER & + & 36 & CIT & - \\
\hline 37 & MNT & - & 38 & - & & 39 & 5 KG & + & 40 & ILATK & + & 41 & AGLU & - & 42 & SUCT & + \\
\hline 43 & NAGA & - & 44 & AGAL & + & 45 & PHOS & - & 46 & GlyA & + & 47 & ODC & - & 48 & LDC & - \\
\hline 49 & - & & 50 & - & & 51 & - & & 52 & - & & 53 & IHISa & - & 54 & - & \\
\hline 55 & - & & 56 & CMT & + & 57 & BGUR & + & 58 & O129R & + & 59 & GGAA & - & 60 & - & \\
\hline 61 & IMLTa & + & 62 & ELLM & - & 63 & - & & 64 & ILATa & + & & & & & & \\
\hline
\end{tabular}




\section{5- Pseudomonas aeruginosa (98\% probability), Bio number}

(0694212003231231)

\begin{tabular}{|c|c|c|c|c|c|c|c|c|c|c|c|c|c|c|c|c|c|c|}
\hline \multicolumn{11}{|c|}{ Table 6: Biochemical details of Pseudomonas aeruginosa } \\
\hline 1 & - & & 2 & APPA & - & 3 & ADO & - & 4 & PyrA & - & 5 & IARL & - & 6 & - & \\
\hline 7 & dCEL & - & 8 & - & & 9 & BGAL & - & 10 & H2S & - & 11 & BNAG & - & 12 & AGLTP & - \\
\hline 13 & dGLU & + & 14 & GGT & - & 15 & OFF & - & 16 & - & & 17 & BGLU & - & 18 & dMAL & - \\
\hline 19 & dMAN & + & 20 & dMNE & + & 21 & BXYL & - & 22 & BAlap & - & 23 & proA & - & 24 & - & \\
\hline 25 & - & & 26 & LIP & - & 27 & PLE & - & 28 & - & & 29 & TyrA & + & 30 & - & \\
\hline 31 & URE & - & 32 & dSOR & - & 33 & SAC & + & 34 & dTAG & - & 35 & dTER & + & 36 & CIT & - \\
\hline 37 & MNT & - & 38 & - & & 39 & 5 KG & - & 40 & ILATK & - & 41 & AGLU & - & 42 & SUCT & - \\
\hline 43 & NAGA & - & 44 & AGAL & - & 45 & PHOS & + & 46 & GlyA & - & 47 & ODC & - & 48 & LDC & - \\
\hline 49 & - & & 50 & - & & 51 & - & & 52 & - & & 53 & IHISa & - & 54 & - & \\
\hline 55 & - & & 56 & CMT & + & 57 & BGUR & - & 58 & O129R & - & 59 & GGAA & - & 60 & - & \\
\hline 61 & IMLTa & - & 62 & ELLM & + & 63 & - & & 64 & ILATa & - & & & & & & \\
\hline
\end{tabular}

\section{3- Molecular identification (PCR and sequencing):}

The sequencing of four bacterial 16S rRNA gene were identified, two isolates were identified as Aeromonas veronii and the other two isolates were identified as Staphylococcus epidermidis and Acinetobacter lwoffii. The nucleotide sequences of the 16S rRNA gene of Aeromonas veronii (two isolates), Staphylococcus epidermidis and Acinetobacter lwoffii were submitted to the GenBank sequence database under the accession numbers MT293773, MT293858, MT293804 and MW393763 respectively.

\section{3- Pathogenicity Test Result:}

Tilapia fingerlings exposed to Aeromonas veronii, Staphylococcus epidermidis and Providencia rettgeri revealed $20 \%$ mortality rate showing slight hemorrhagic changes all over the body. Whereas with PM examination mortality rate showed slight hemorrhagic changes along the intestinal tract, while control group did not exhibit any mortality.

Table 7: Mortality rates of inoculated bacterial isolates.

\begin{tabular}{|c|c|}
\hline Bacterial isolate & Mortality rate \\
\hline Aeromonas veronii & $20 \%$ \\
\hline Staphylococcus epidermidis & $20 \%$ \\
\hline Providencia rettgeri & $20 \%$ \\
\hline Control Group & $0 \%$ \\
\hline
\end{tabular}




\section{DISCUSSION}

Mass mortality of fish fries following transportation stress to larger farming ponds is a common phenomenon in aquaculture. Understanding the different etiological factors behind it is critical to boost the productivity and efficiency of fish farms. In this study, the role of prevalent pathogens in this vulnerable fish population in Egypt was investigated. A total of 9 different bacterial pathogens were isolated from the Nile tilapia fries in Kafr El Sheikh which are known for causing mortalities in adult fish.

Water quality was also investigated as a probable cause for mass mortality. In Kafr El Sheikh, fish farming relies on earthen ponds supplied by runoff water from agricultural fields. Four water samples taken over the year revealed high levels of ammonia in sample 1 (spring) and 2 (summer), reflecting the impact of varying fertilizing cycles on the quality of wastewater from the field. The high degree of biochemical contamination is indicated by the respective BOD and COD scores for these samples. Notwithstanding, sampled fish fries did not exhibit asphyxia typical signs of respiratory distress associated with ammonia toxicity. This could be attributed to tilapia's high tolerance of impaired water quality, elevated concentrations of ammonia, and low levels of dissolved oxygen and the dietary inclusion of prebiotic mix- ture (bG \& MOS) and fully fermented yeast S. cerevisiae which enhance immune response and disease resistance in the Nile tilapia (Boyd, 2004; Abu-elala et al., 2018; Abu-elala et al., 2020b). However, chronic exposure to high levels of ammonia is known to severely affect fish physiological parameters and growth performance, which, left unchecked, would inevitably impact survival rate of fish fries (Al Kobaby \& Hassanien, 2007; Hegazi, 2011).

Compared to tank-based aquaculture and wild water, direct contamination by bacteria from surrounding soils contribute to the high prevalence and diversity of bacteria in earthen ponds.In this study, Aeromonas sobria, Aeromonas hydrophila, Aeromonas veronii, Shigella sonnei, Pseudomonas aeruginosa and Staphylococcus epidermidis were isolated. These have been repeatedly isolated in adult fish farms in Egypt (David et al., 2009; El-Hady \& Samy, 2011; Pridgeon \& Klesius, 2012; Zg et al., 2016; El-Barbary \& Hal, 2016; Zg, 2017; Atteia et al., 2018).

In adult tilapia fish, infection by Pseudomonas and Aeromonas bacteria typically causes hemorrhage, detachment of scales, and ulceration (Lamiaa et al., 2016). A. hydrophila and Staphylococcus strains are also known to result in high mortality rates in freshwater aquaculture (Shalaan et al., 2018). Elsheshtawy et al. (2019) have recently linked A. hydrophila to mass mortality in the Nile tilapia farms in Kafr El Sheikh. 
Providencia rettegri, an opportunistic gram-negative bacterium, has been rarely isolated in fish farms in Egypt in recent years. In the literature, Faisal et al. (1987) were able to first isolate $P$. rettegri in Edfina, Egypt using the API-20E system following summer mass mortality of the Nile tilapia in the mid-1980s. In this study, success in isolating $P$. rettegri is related, in part, to using the Vitek2 system which offers an extensive identification menu and significantly reduces time for correct microbiological identification, including gram-negative bacteria, with a probability score to gauge reliability (Nonhoff et al., 2005).

$P$. rettegri affects both man and fish which gives it zoonotic significance. In man, it is an emerging urinary tract pathogen, mostly in older catheter-using patients, but it has also been implicated as the causative agent of gastrointestinal illness, traveler's diarrhea, ocular infection; and it is often resistant to multiple antibiotics (Muller, 1986; Koreishi et al., 2006; Wie, 2015; Sagar et al., 2017). In the Nile tilapia, the clinical picture included severe dyspnea and exophthalmia, extremely pale and swollen gills, complete loss of the flight reflex, darkening of the skin color, reddening of the anal region, and lepidarthosis (Faisal et al., 1987). Recently, De Freitas Souza et al. (2019) demonstrated that $P$. rettegri causes severe oxidative stress in liver and kidney tissues of the Nile tilapia which contributes to pathogenic manifestations. However, it remains unclear whether concomitant stressors and/or immune suppression are necessary for a $P$. rettegri infection to overpower the host and result in full-blown pathogenesis.

In this study, examiners succeeded to isolate another emerging freshwater pathogen, Shewanella putrefaciens, an opportunistic gram-negative bacterium that is more commonly found in marine fish and has only been recently described as pathogen of several freshwater fish by Pezkala et al. (2015). Diseased fish were reported to suffer from lethargy, swollen abdomen, skin discoloration, and degenerative changes in the kidney, liver, spleen, and intestine (Altun et al., 2013; Pezkala et al., 2015).

El-Barbary (2017) isolated $S$. putrefaciens for the first time in Egypt from cultured adult Nile tilapia near El Manzala lake using API20- NE. In addition, a recent report implicated it in mass mortality of cultured Nile tilapia in India (Sood et al., 2020). This study successfully isolated $S$. putrefaciens from non-diseased tilapia fries in Egypt also using API20NE, suggesting it is more commonly present in freshwater ecosystems as postulated by Lu and Levin (2010). Like P. rettegri, S. putrefaciens has possible zoonotic potential, having been incidentally implicated in some secondary infections of immunocompromised patients (Holt et al., 2005).

In this study, researchers succeeded to isolate Acinetobacter lwoffii, an opportunistic gram-negative bacterium, and diseased fish were reported to suffer from listless, loss of appetite, emergence to the water surface, lethargy ,skin ulcers, haemorrhage around the mouth, congested fins, exophthalmia, opaque lenses and bleeding of internal organs (Cao et al., 2018). It also has a zoonotic effect as it causes 
meningitis, bacteremia, peritonitis, pneumonia, endocarditis, gastritis and urinary tract infection (Rathinavelu et al., 2003; Debarry et al., 2007; Elsayyed et al., 2010).

In spite of the presence of the above pathogens, no pathological abnormalities were observed upon clinical examination of sampled fish fries. Lethargy, skin lesions, or signs of sepsis were not present. In addition, inoculation of fish fingerlings with $A$. veronii, $S$. epidermidis, and $P$. rettegri resulted in a maximal mortality rate of only 20 percent after 3 weeks despite the confirmed high pathogenicity of these strains in adult fish.

These findings suggest that, at least in non-stress conditions, pathogenic factors do not independently trigger bacterial mass mortality at this stage of development in juvenile fish. Instead, a combination of factors may contribute to heightened mortality. Overcrowding and transient hypoxia during the transportation process as well as sudden changes in the culture medium from hatcheries to farming ponds may challenge the homeostatic capacity of the tilapia fries, weaken their immune system, and threaten their survival. Transportation stress has clear adverse impacts on physiological parameters like liver enzymes and thyroid hormones (El-Khaldi, 2010), while mechanical injury from manipulation and collection also increases chances of fine erosions and lesions that raise susceptibility to secondary infections (Tørud \& Håstein, 2008). Further, loss of temperature control in larger farming ponds and shifts in $\mathrm{pH}$ of the culture water of each pond, being impacted by the fertilizing cycles of nearby fields, would increase the vulnerability of the tilapia that survive at optimal temperatures of 24-30C (El Sayed \& Kawanna, 2008) and $\mathrm{pH}$ of 7 to 8 (El-Sherif \& EL-Feky, 2008).

\section{CONCLUSION}

The interplay of multiple co-stressors in the etiology of bacterial mass mortality in fish farms needs to be better recognized. Although the tilapia fish are typically resilient and disease resistant, making it globally the second most cultured fish species (Ng \& Romano, 2013), while in the presence of multiple environmental and pathogenic stressors, incidents of mass mortality can occur. This is most evident in the case of opportunistic pathogens. For example, El-Barbary (2017) and Sood et al. (2020) described that low temperatures (15-20 C) in fish farms experience outbreaks of S. putrefaciens, while Faisal et al. (1987) suggested that mature females stressed by countercurrents near the Edfina dam during spawning season were more affected by $P$. rettegri infection.

More generally, reducing environmental stressors could increase resilience to even typical pathogens. Charo-Karisa et al. (2004) highlighted the role of cold stress in mass mortality of juvenile tilapia and emphasized the importance of size in cold 
tolerance. In this context, adequate acclimatization of fries to new culture medium and optimization of rearing pond conditions prior to fries' transfer could prove a key to reduce shock, preserve fish immunity and minimize vulnerability to both typical and opportunistic pathogens.

\section{REFERENCES}

\section{Abdelsalam, M.; Elgendy, M.Y. ; Shaalan, M.; Moustafa, M. and Fujino, M.} (2017). Rapid identification of pathogenic streptococci isolated from moribund red tilapia (Oreochromis spp.). Acta Vet. Hung., 65(1): 50-59.

Abu-elala, N.M. ; Younis, N.A. ; Abubakr, H.O. ; Ragaa, N.M. ; Borges, L.L. and Bonato, M.A. (2018). Efficacy of dietary yeast cell wall supplementation on the nutrition and immune response of Nile tilapia. Egypt. Aquat. Biol. Fish., 64(4): 409.

Abu-elala, N.M.; Abd-Elsalam, R.M. and Younis, N.A. (2020a). Streptococcosis , Lactococcosis and Enterococcosis are potential threats facing cultured Nile tilapia ( Oreochomis niloticus) production. Aquaculture research., 51(10): 4183-4195.

Abu-elala, N.M. ; Younis, N.A. ; AbuBakr, H.O. ; Ragaa, N.M.; Borges, L.L. and Bonato, M.A. (2020b). Influence of dietary fermented Saccharomyces cerevisiae on growth performance, oxidative stress parameters, and immune response of cultured Oreochromis niloticus. Fish Physiology and Biochemistry., 46(4): 533-545.

Alkobaby, A.I. and Hassanien, H.A. (2007). Acute and Chronic Ammonia Toxicity to Nile. Egypt. Aquat. Biol. Fish., 33(1): 455-464.

Altschul, S.F. ; Gish, W.; Miller, W.; Myers, E.W. and Lipman, D.J. (1990). Basic local alignment search tool. Journal of Molecular Biology., 215(3): 403-410.

Altun, S.; Büyükekiz, A.G. ; Duman, M.; Özgür, Ö.M. and Karataş, S.E. (2013). TurgayIsolation of Shewanella putrefaciens from Goldfish (Carassius auratus). The Israeli Journal of Aquaculture., 66: 956-962.

APHA (American Public health Association), (2005). Standard methods for the examination of water and wastewater, 21 Ed., Washington D.C. 345pp.

Attia, A.S.A. ; Khedr, M.H.E. and Zaki, M.S. (2018). Occurrence of Potentially Pathogenic Aeromonas Species Isolated from Raw and Ready- to- Eat fish Marketed in Sharkia Governorate, Egypt. Zagazig Veterinary Journal., 46(2); 154-159.

Austin, B. and Austin, D.A. (2007). Bacterial Fish Pathogens, Diseases of Farmed and Wild Fish. Fourth Edition. Praxis Publishing Ltd., Chichester, UK. 552pp. 
BioMe'rieux. (2006). Vitek2 product information, document 510769-4EN1. bioMe'rieux, Inc., Durham, NC.Bull. Eur. Ass. Fish Pathol., 24 (2004), pp. 199-203.

Boyd, C.E. (2004). Farm- level issues in Aquaculture certification; Tilapia.Report commissioned by WWF-US in 2004. Auburn University, Alabama, pp. 1-29.

Cao, S.; Geng, Y.; Yu, Z.; Deng, L.; Gan, W.; Wang, K.; Ou, Y.; Chen, D.; Huang, X.; Zuo, Z.; He, M. and Lai, W. (2018). Acinetobacter lwoffii, an emerging pathogen for fish in Schizothorax genus in China. Transboundary and Emerging Diseases., 65(6): 1816-1822.

Charo-Karisa, H.; Rezk, M.A. ; Bovenhuis, H. and Komen, H. (2004). Effects of Rearing Conditions on Low-Temperature Tolerance. Proceedings of the 6th international symposium on tilapia in aquaculture, Manila, Philippines, 12-16 September 2004 - pp. 30 - 41.

David, O.M. ; Wandili, S.; Kakai, R. and Waindi, E.N. (2009). Isolation of Salmonella and Shigella from fish harvested from the Winam Gulf of Lake Victoria, Kenya. Journal of infection in Developing Countries., 3(2): 99-104.

De Freitas Souza, C.; Baldissera, M.D. ; Verdi, C.M. ; Santos, R.C.V. ; Da Rocha, M.I.U.M. ; da Veiga, M.L. ; da Silva, A.S. and Baldisserotto, B. (2019). Oxidative stress and antioxidant responses in Nile tilapia Oreochromis niloticus experimentally infected by Providencia rettgeri. Microbial Pathogenesis., 131: 164169.

\section{Debarry, J.; Garn, H.; Hanuszkiewicz, A.; Dickgreber, N.; Blümer, N.; Mutius, E.V.} and Holst, O. (2007). Acinetobacter lwoffii and Lactococ-cus lactis strains isolated from farm cowsheds possess strong allergy- protective properties. The Journal of Allergy and Clinical Immunology., 119: 1514-1521.

El-Barbary, M.I. (2017). First recording of Shewanella putrefaciens in cultured Oreochromis niloticus and its identification by 16Sr RNA in Egypt. Egypt. Aquat. Biol. Fish., 43(1): 101-107.

El-barbary, M.I. and Hal, A. (2016). Isolation and molecular characterization of some bacterial pathogens in El- Serw fish farm, Egypt. Aquat. Biol. Fish., 20(4): 115-127.

El-Hady M.A. and Samy, A.A. (2011). Molecular Typing of Pseudomonas Species Isolated from Some Cultured Fishes in Egypt. Global Veterinaria., 7(6): 576-580.

El-jakee, J.; Elshamy, S.; Hassan, A. and Abdelsalam, M. (2020). Isolation and characterization of Mycoplasmas from some moribund Egyption fishes. Aquaculture international journal., 28: 901-912. 
El-Khaldi, A.T.F. (2010). Effect of different stress factors on some physiological parameters of Nile tilapia (Oreochromis niloticus). Saudi Journal of Biological Sciences., 17(3): 241-246.

El-Sayed, A.F.M. and Kawanna, M. (2008). Optimum water temperature boosts the growth performance of Nile tilapia (Oreochromis niloticus) fry reared in a recycling system. Aquaculture Research., 39(6): 670-672.

El-Sherif, M.S. and El-Feky, A.M. (2008). Effect of Ammonia on Nile Tilapia (O. niloticus) Performance and some Hematological and Histological Measures. 8th International Symposium on Tilapia in Aquaculture, October 2008, pp. 513-530.

Elsayyad, H.I. ; Zaki, V.H. ; Elshebly, A.M. and Elbadry, D.A. (2010). Studies on the effects of bacterial diseases on skin and gill structure of Clarias gariepinus in Dakahlia Province, Egypt. Annals of Biological Research., 4: 106-118.

Elsheshtawy, A.; Yehia, N.; Elkemary, M. and Soliman, H. (2019). Investigation of Nile tilapia summer mortality in Kafr El-Sheikh governorate, Egypt. Genetics of Aquatic Organisms., 3(1): 17-25.

Faisal, M.; Popp, W. and Refai, M. (1987). High mortality of the Nile tilapia Oreochromis niloticus caused by Providencia rettgeri, Berl. Münchener Tierärztliche Wochenschr., 100: 238-240.

FAO. (2016). The State of World Fisheries and Aquaculture. Rome, Italy.

FAO. (2018). FishStatJ - Software for Fishery and Aquaculture Statistical Time Series. Rome, Italy.

GAFRD. General authority for fish resources development. (2014). In: Fish Statistics Yearbook. Cairo, Egypt: Ministry of Agricul- ture and Land Reclamation, pp. 12011227.

Harris, J.O. ; Greg, B.M. ; Stephen, E. and Stephen, M.H. (1998). Effect Of ammonia on the growth rate and oxygen juvenile green lip consumption of abalone, Haliotis laevigata Donovan. Aquaculture., 3: 259-272.

Hassan, M.A. ; Noureldin, E.A.; Mahmoud, M.A. and Fita, N.A. (2017). Molecular identification and epizootiology of Aeromonas veronii infection among farmed Oreochromis niloticus in Eastern Province, KSA. Egyptian Journal of Aquatic Research., 43(2): 161-167. 
Hegazi, M. (2011). Effect of chronic exposure to sublethal of ammonia concentrations on NADP+-dependent dehydrogenases of Nile tilapia liver. Egyptian Journal of Aquatic Biology and Fisheries., 15(1): 15-28.

Holt, H.M. ; Gahrn-Hansen, B. and Bruun, B. (2005). Shewanella algae and Shewanella putrefaciens: clinical and microbiological characteristics. Clinical Microbiology and Infection. The Official Publication of the European Society of Clinical Microbiology and Infectious Diseases., 11(5):347-352.

Huang, S.L. ; Chen, W.C. ; Shei, M.C. ; Liao, I.C. and Chen, S.N. (1999). Studies on epizootiology and pathogenicity of Staphylococcus epidermidis in tilapia (Oreochromis spp.) cultured in Taiwan. Zoological Studies., 38(2): 178-188.

Khairul Afizi, M.S. ; Siti Fatimah, B.S. ; Mariana N.S. and Abdel-Hadi, Y.M. (2013). Herbal and Antibiotic Resistance of AeromonasBacteria Isolated from Cultured Fish in Egypt and Malaysia. Journal of Fisheries and Aquatic Science., 8: 425- 429.

Khalil S.A. ; Khalil R.H. ; Saad T.T. and Safaa M.H. (2010). Studies on Pseudomonas Septicemia among Cultured Oreochromus niloticus. Journal of the Arabian Aquaculture Society., 5(1): 55.

Koreishi, AF.; Schechter, BA. and Karp, CL. (2006). Ocular infections caused by Providencia rettgeri. Ophthalmology., 113(8):1463-66.

Lamiaa, A.O. ; Ammar , A.; Maha, A.E.H. ; Samir, A.; Samy, A.; Abdelmegeid, M. and El-jakee, J. (2016). Identification of common fish bacterial pathogens in kafr El Sheikh Governate Egypt using PCR. International Journal of Biology, Pharmacy and Allied Science., 5(2): 522-537.

Lu, Sh. and Levin, R. (2010). Shewanella in a Tilapia Fish Farm. Journal of FisheriesSciences., 4: 159-170.

Moustafa, M.; Mohamed, L.A. ; Mahmoud, M.A. ; Soli- man, W. S. and El-Gendy M.Y. (2010). Bacterial infections affecting marine fishes in Egypt. Journal of American Science., 6(11): 603-612.

Muller, HE. (1986). Occurrence and pathogenic role of Morganella-Proteus-Providencia group bacteria in human feces. Journal of Clinical Microbiology., 23(2): 404- 405.

Ng, W.K. and Romano, N. (2013). A review of the nutrition and feeding management of farmed tilapia throughout the culture cycle. Reviews in Aquaculture., 5: 220-254. 
Nonhoff, C.; Rottiers, S. and Struelens, M.J. (2005). Evaluation of the Vitek 2 system for identification and antimicrobial susceptibility testing of Staohylococcuys spp. Clinical Microbiology and Infection journal., 11(2): 150-153.

Noor El Deen, A.E. ; Dorgham, S.M. ; Hassan, A.H.M. and Hakim, A.S. ( 2014). Studies on Aeromonas hydrophila in Cultured Oreochromis niloticus at Kafr El Sheikh Governorate, Egypt with Reference to Histopathological Alterations in Some Vital Organs. World Journal of Fish and Marine Sciences., 6(3): 233-240.

\section{Panangala V.S. ; Shoemaker C.A. ; Van, S.; Vicky, L.; Dybvig, K. and Klesius, P.H.} (2007). Multiplex-PCR for simultaneous detection of 3 bacterial fish pathogens,columnare, ictaluri, Aeromonas hydrophilia and Flavobacterium Edwardsiella. Diseases of Aquatic Organisms., 74: 199-208.

Pezkala, A.; Kozinska, A.; Pazdzior, E. and Głowacka, H. (2015). Phenotypical and genotypical characterization of Shewanella putrefaciens strains isolated from diseased freshwater fish. J. Fish Dis., 38: 283-293.

Pridgeon, J.W. and Klesius, P.H. (2012). Major bacterial diseases in aquaculture and their vaccine development. CAB International., 7(048): 2-11.

Quinn, P.J. ; Markey, B.K. ; Donnelly, W.J. ; Leonard, F.C. ; Fanning, S. and Maguire, D. (2011). Veterinary Microbiology and Microbial disease. A Blackwell publishing Company., Iowa, 928pp.

Ramesh, D. and Souissi, S. (2018). Antibiotic resistance and virulence traits of bacterial pathogens from infected freshwater fish, Labeo rohita. Microbial Pathogenesis., 116 : 113-119.

Rathinavelu, S.; Zavros, Y. and Merchant, J.L. (2003). Acinetobacter lwoffii infection and gastritis. Microbes and Infection., 5: 651-657.

Sadek, S. (2013). Aquaculture site selection and carrying capacity estimates for inland and coastal aquaculture in the Arab Republic of Egypt. In L.G. Ross, T.C. Telfer, L. Falconer, D. Soto \& J. Aguilar-Manjarrez, eds. Site selection and carrying capacities for inland and coastal aquaculture., 21: 183-196.

Sagar, S.; Narasimhaswamy, N. and D'Souza, J. (2017). Providencia rettgeri: An emerging nosocomial uropathogen in an indwelling urinary catheterised patient. Journal of Clinical and Diagnostic Research., 11(6): 01-02.

Shaalan, M.; El-Mahdy, M.; Saleh, M. and El-Matbouli, M. (2018). Aquaculture in Egypt: Insights on the Current Trends and Future Perspectives for Sustainable Development. Reviews in Fisheries Science \& Aquaculture., 26(1): 99-110. 
Sood, N.; Pradhan, P.K. ; Ravindra; Verma, D.K. ; Yadav, M.K. ; Mishra, R.K. ; Kumar, U.; Swaminathan, T.R. and Sood, N.K. (2020). Large-scale mortality in cultured tilapia Oreochromis niloticus due to infection with Shewanella putrefaciens in India. Journal of the World Aquaculture Society., 51(2): 563-570.

Subasinghe, R.; Soto, D. and Jia, J. (2009). Global aquaculture and its role in sustainable development. Reviews in Aquaculture., 1: 2-9.

Tørud, B. and Håstein, T. (2008). Skin lesions in fish: Causes and solutions. Acta Veterinaria Scandinavica., 50(1): 1-3.

Wang, Q.; Cheng, L.; Liu, J.; Li, Z.; Xie, S. and De Silva, S. S. (2015) Freshwater aquaculture in PR China: Trends and prospects. Rev. Aquacult., 7(4): 283-302.

Weisburg, W.G. ; Barns, S.M. ; Pelleitier, D.A. and Lane, D.J. (1991). 16S Ribosomal DNA Amplification for Phylogenetic study. Journal of Bacteriology., 173(2): 697703.

Whitman, KA. and MacNair, NG. (2004). Finfish and Shellfish. Bacteriology Manual Techiniques and Procedures. A Blackwell publishing Company., Iowa, 258pp.

Wie, S.H. (2015). Clinical significance of providencia bacteremia or bacteriuria. Korean journal of internal Medicine., 30(2): 167-169.

Zg, H. (2017). Pathogenic Bacteria in Oreochromis Niloticus Var. Stirling Tilapia Culture. Fisheries and Aquaculture Journal., 8(2): 2-7.

Zg, H.; Cj, L. and De, P.R. (2016). Current State of Bacteria Pathogenicity and their Relationship with Host and Environment in Tilapia Oreochromis niloticus. Journal of aquaculture research and development., 7(5): 2-10.

Zhang, D.F. ; Zhang Q.Q. and Li, A.H. (2014). Development of a multiplex PCR assay for rapid and simultaneous detection of four genera of fish pathogenic bacteria. Letters in Applied Microbiology., 59(5): 471-478. 


\section{ARABIC SUMMARY}

دراسة حول مسببات الامراض البكتيرية الثائعة بزريعه اسماك البلطي بمحافظه كفر الثيخ - مصر

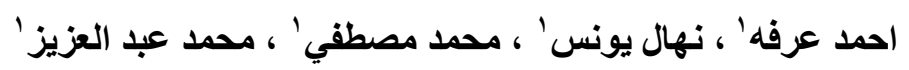

$$
\text { قسم طب ور عاية الحيوان - كلية الطب البيطري - جامعة القاهرة - الجيزة - مصر }
$$

في الآونة الأخيرة عانت تربيه الاحياء المائية في مصر من ارتفاع معدل الوفيات مها ادي الي خسائر اقتصاديه

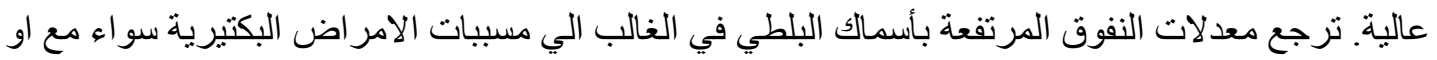

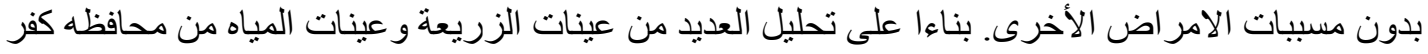

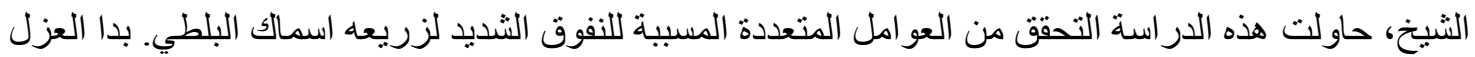

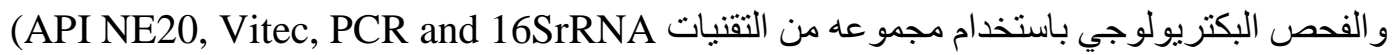
وكثف عن مجمو عه من مسببات الامر اض المعروفة بانها تسبب عدوي قاتله لاسماك البلطي Sequencing) البالغة. الأنو اع الني تم عزلها بكثره كانت:

Aeromonads (A. veronii, A. sobria A. hydrophila) $\%$ r $\bullet$

Staphylococcus epidermidis \%'1,' •

Pseudomonas aeruginosa \%11.1

Shigella sonnei \%11.1 •

علاوة على ذلك تم عزل ثلاث مسببات للأمر اض البكتيرية والني تنتقل الي الانسان وهي:

Providencia rettgeri \%1!.!

Shewanella putrefaciens $\% 11.1$ •

Acinetobacter lwoffii \% 1).1

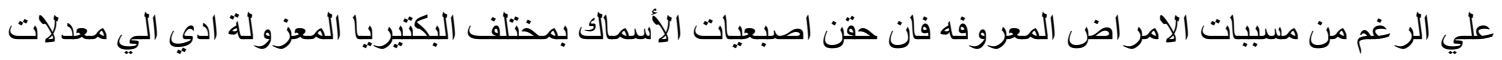

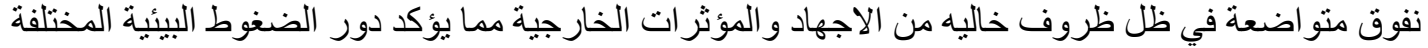
و الإضافية التي تسبب نفوق جماعي للأسماك الصغيرة.

وبالتأكيد فان هذه العو امل الممرضة لها نأثير سلبي كبير على زريعه اسماك البلطي خاصه عندما تتو اجد مع عوامل

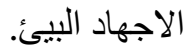

